superseded by a clear grey, a process the progress of which I watched in a specimen which lived for many years in the Gardens of the Zoological Society.

Mr. Sharpe also includes amongst the Buteoninæ the genera Morphnus and Thrasaëtus; but as these appear to me to be, notwithstanding their scutellated tarsi, essentially Hawk Eagles, I defer their consideration until I reach that group.

XLVI.-On some new Species of Birds from Western Ecuador. By Osbert Salvin, M.A., F.R.S., \&c. (Plate XIV.)

Mr. C. Buckley, who recently enriched Mr. Godman's and my collection by sending us a large series of bird-skins from Bolivia, is now collecting in Ecuador, having, on leaving Bolivia, paid a few months' visit to this country. During his absence from South America he instructed his native assistant, Señor Villagomez, whom he left at Guayaquil, to proceed to Puna Island and to make an excursion into the Province of Loxa in quest of butterflies and birds. On Mr. Buckley's return to Guayaquil from England, he found Villagomez had returned with collections; and he at once forwarded the birds to us through his agent, Mr. E. T. Higgins.

The collection altogether contains specimens of 140 species of birds, many of which are of considerable interest, and some new to science. These last I now propose briefly to describe, reserving a more detailed account of the whole series to a future occasion, by which time I trust we shall receive other collections from Mr. Buckley, who, I understand, has now proceeded into the interior of Ecuador, and is working in some of the valleys of the eastern slope of the Andes.

\title{
Euscarthuus ocularis.
}

Supra olivaceo-viridis, fronte media obscuriore : loris et regione ante oculos pallide fulvescentibus : gutture nigro : gula media et ventre imo albis, pectore grisescente : alis et cauda fuscis viridi limbatis, tectricibus subalaribus 
flavissimis : rostro fusco, pedibus carneis : long. tota $3 \cdot 7$, alæ $1 \cdot 8$, caudæ $1 \cdot 6$, rostri a rictu $\cdot 55$, tarsi $\cdot 6$.

Hab. "Puna I.," et "San Lucas," rep. Equat.

Obs. E. granadensi affinis, loris fulvis nec albis distinguendus.

This species agrees closely with $E$. granadensis in every respect but the colouring of the large loral spot. As the two specimens sent agree in having this mark tinged with fulvous, I conclude that they belong to a race allied to, but distinct from, $E$. granadensis.

Formicivora SPECIOSA.

$\delta$ fronte media, capite summo cum nucha, stria per oculos ad nucham producta et torque pectorali nigris : stria superciliari a naribus ad dorsum extensa, gutture et colli lateribus albis cervino tinctis : dorso fusco-brunneo, alis et cauda nigris, hac griseo limbata, rectricibus duabus externis utrinque albido marginatis, illis primariorum sex externorum marginibus albis, reliquis dorsi colore pictis : secundariis intimis et tectricibus alarum majoribus castaneis nigro medialiter notatis : tectricibus minoribus et alula spuria nigris albo marginatis : pectore læte castaneo, ventre pallidiore: tibiis et crisso cervinis : rostro nigro, pedibus carneis : long. tota $6 \cdot 0$, alæ $2 \cdot 3$, caudæ $2 \cdot 5$, rostri a rictu $0 \cdot 7$, tarsi $1 \cdot 0$.

o mari similis sed corpore subtus a torque pectorali ad crissum cervino unicolori, tectricibus quoque alarum castaneiis pallidioribus : long. tota $5 \cdot 4$, alæ $2 \cdot 2$, caudæ $2 \cdot 4$, rostri a rictu $0 \cdot 65$, tarsi $0 \cdot 9$.

Hab. "Puna I.," rep. Aquat.

This very well-marked and beautiful species, though quite unlike any other member of the genus in its coloration, comes perhaps nearer to $F$. strigilata, Max., than any other. The conspicuous markings of the head, the white throat, tinged with fawn-colour, the black pectoral band, and the deep-chestnut breast of the male, as well as other minor features, render it a remarkable bird. The collection contains only three specimens, one male and two females, all from Puna Island.

Capito squamatus. Plate XIV.

Nitenti-niger, fronte rubra, vertice albido nucham versus brunneo marginato: dorso, uropygio, et alarum tectricibus 


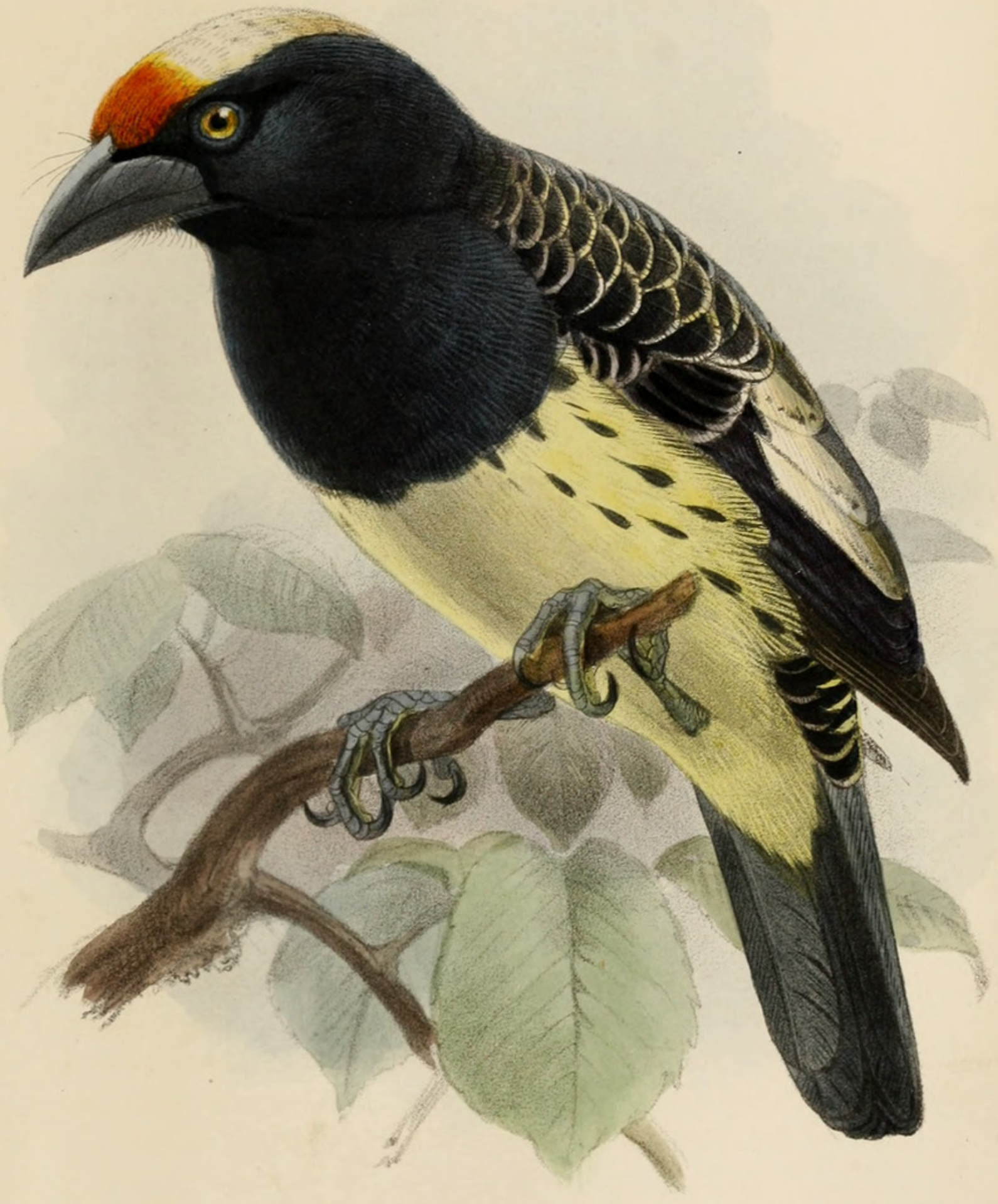


stricte albo marginatis : secudariorum trium internorum pogoniis externis plaga magna albida notatis: ventre pallidissime flavo, hypochondriis nigro maculatis : rostro et pedibus plumbeis : long. tota $7 \cdot 0$, alæ $3 \cdot 3$, caudæ $2 \cdot 2$, rostri a rictu $1 \cdot 0$, tarsi 0.85 .

Hab. "Santa Rita," rep. Equat.

The collection contains but a single specimen of this remarkable species, of which the sex, unfortunately, is not marked. The prevailing rich black colour of the plumage suggests perhaps an alliance with $C$. maculicoronatus, in which the female has the whole throat and chest black, as in the present bird. This would lead one to suppose that this specimen is a female; but the colour of the head is perhaps opposed to this view. The point cannot be settled until more specimens have been examined.

\section{Pionopsitta PyrRhops.}

Prasina, facie (oculorum ambitu incluso), humeris, tectricibus subalaribus minoribus et macula ventrali coccineis : vertice antico, regione parotica, et tectricibus auricularibus aureo vix tinctis, vertice postico cæruleo lavato : primariis extus et caudæ apicibus purpurascenti-cæruleis : rostro pallido, pedibus plumbeis : long. tota $9 \cdot 0$, alæ $5 \cdot 6$, caudæ $3 \cdot 5$, tarsi $0 \cdot 5$.

Hab. "Santa Rita” et “San Lucas," rep. Equat.

Obs. P. amazonince (Des Murs, Icon. Orn. t. 15) affinis sed colore coccineo capitis superioris fronti restricto et caudæ basi viridi nec rubra distinguendus.

There are two specimens of this pretty species in the collection. It is evidently a close ally of $P$. amazonina, but separable by the characters pointed out above. In addition to these the lores are rather deeper red, and not tinged with yellow, as is the case with the allied bird. P. amazonina, too, has the green of the upper breast and sides of the neck rather more tinged with yellow.

$P$. amazonina was placed by $\mathrm{Mr}$. Sclater and myself in the genus Caica in our 'Nomenclator Av. Neotr.;' but a reexamination of this species with that now described, and with recently acquired specimens of $P$. melanotis (Lafr.), has convinced me that its proper position is in the genus Piono- 
psitta. The tail of this genus is longer and more cuneiform than in Caica, and the bill is more feeble.

Pionopsitta was, by an oversight, omitted from our ' Nomenclator.' As far as I know them, the species that should be included in it are the following :-

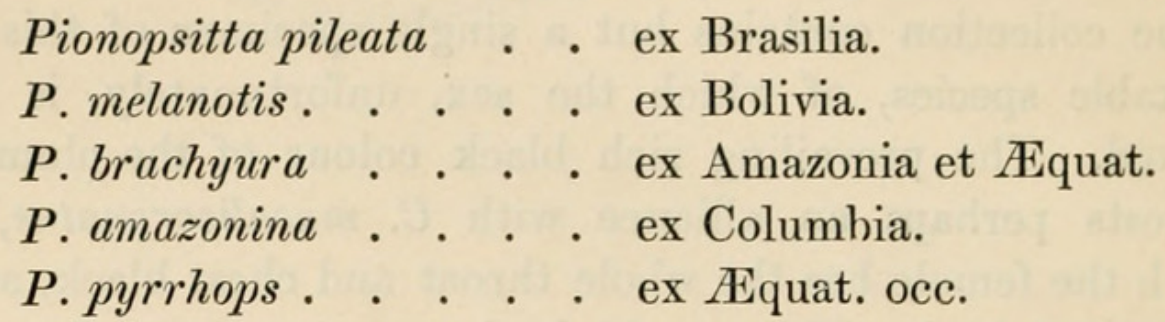

\section{Leucopternis occidentalis.}

Supra saturate plumbeus fere unicolor : dorso postico et uropygio albis, hoc plumbeo variegato: capite summo et nucha albo vix intermixto: primariis plumbescenti-nigris, secundariis albo terminatis et nigro obsolete transfasciatis, tectricibus humeralibus albo punctatis : cauda alba, fascia lata subterminali nigra, apice alba : subtus albus, genis et colli lateribus fasciis minutis notatis : pagina inferiore alarum alba : remigibus et secundariis intus nigro transfasciatis, apicibus nigris : rostro et cera plumbeo-nigris, pedibus flavis : long. tota $18 \cdot 0$, alæ $14 \cdot 0$, caudæ $8 \cdot 0$, rostri a rictu $1 \cdot 6$, tarsi $3 \cdot 0$.

Hab. Rep. Aquat. occident.

Obs. L. albicolli affinis sed capite summo plerumque plumbeo nec albo, colore supra plumbescentiore et fascia caudali angustiore distinguendus.

The label giving the precise locality where this bird was shot has unfortunately been lost; but the habitat of the species may be assigned to the Province of Loxa or Puna Island, where alone Villagomez collected.

No species of this form has hitherto been noted from Ecuador; so that one might well have been expected from there. Moreover, as the range of most of the species of this genus is limited to circumscribed districts, it is not surprising to find this bird differing from its more eastern ally*.

* Since the above was in type Mr. Gurney's note (anteà, p. 473) recording the existence of a specimen of $L$. albicollis from "Quito" in the Norwich Museum has come before me. The bird I now describe is doubtless the representative of $L$. albicollis in the western forests of the 


\section{$2 \mathrm{BHL}$ Biodiversity Heritage Library}

Salvin, Osbert. 1876. "XLVI.-On some new Species of Birds from Western Ecuador." Ibis 6, 493-496. https://doi.org/10.1111/j.1474-919x.1876.tb06944.x.

View This Item Online: https://www.biodiversitylibrary.org/item/35122

DOI: https://doi.org/10.1111/j.1474-919x.1876.tb06944.x

Permalink: https://www.biodiversitylibrary.org/partpdf/156407

\section{Holding Institution}

American Museum of Natural History Library

\section{Sponsored by}

Biodiversity Heritage Library

\section{Copyright \& Reuse}

Copyright Status: NOT_IN_COPYRIGHT

This document was created from content at the Biodiversity Heritage Library, the world's largest open access digital library for biodiversity literature and archives. Visit BHL at https://www.biodiversitylibrary.org. 